\title{
The Use and Value of Green School Grounds in
}

\section{Developing Countries}

\author{
Arlinda Sheqiri ${ }^{1,2}$ and Parna Rastgo ${ }^{3}$ \\ 1. Department of Architecture and Urban Studies, Politecnico di Milano, Milano 20133, Italy \\ 2. Fondazione Fratelli Confalonieri, Milano 20123, Italy \\ 3. Department for Urban and Regional Planning, Technical University of Berlin, Berlin 10623, Germany
}

\begin{abstract}
There is an extensive attention in developed countries to take full advantages of urban green spaces including green school grounds. Those spaces are assessed and established as environmental learning resources, where top-down or bottom-up initiatives encourage or initiate projects with the support of school staffs and students. Green school grounds are also used for gardening (food growing) that besides environmental education, those spaces provide health benefits and knowledge, also skills and behavioral benefits. Those approaches in some developing countries are still vague or inapplicable for several reasons. This paper addresses the use and value of school grounds in developing countries as it lacks the opportunities to make the most of green school grounds. This research elaborated five schools, in the city of Podujevo, Kosovo. The findings reveal that the potentials of green school grounds in most of the cases studied have not been utilized. Opportunities offered by the municipality and environmental NGOs (Non-governmental Organizations) are insufficient. The findings suggest the need to rethink the design and use of green school grounds in developing countries.
\end{abstract}

Key words: School, environment, school gardening, children's gardens, experimental learning.

\section{Introduction}

Green school grounds are utilized as places to facilitate formal, informal and non-formal environmental learning and experiences [1, 2]. Environmental education has gained attention in the last decades about the role it may have to facilitate the current environmental challenges [3, 4, 6]. From 2005, UNESCO has announced the UN Decade of Education for Sustainable Development. That seeks to "integrate the values inherent in sustainable development into all aspects of learning to encourage behavior changes that allow for a more sustainable and just society for all" [5]. Such statements indicate the necessity for environmental education and awareness to be integrated into all levels of education.

Regarding green school grounds as education platforms have been conceived long back from 19th

Corresponding author: Arlinda Sheqiri, Ph.D. candidate, main research fields: urban studies, environment, city planning and design. century, Howard, E. [7] emphasize: "School gardens might be made the means of giving the young an insight into horticulture, the effect of which they would find pleasant and profitable in afterlife..... the school garden would be the most valuable of object-lessons".

Today, studies show that school-based garden programs have significant knowledge and health effects on students [8]. School gardens provide a dynamic environment in which students ${ }^{1}$ can experiment, discover, observe and interact with nature. The assessment of school garden as living laboratory where students can gain an understanding of ecosystems, food origins, the value of nutrition, including knowledge of plant and animal life cycles [6, $9,10]$. Scholars examining urban green commons have pointed to varied ways that food production can foster social-ecological memory [11].

On their research Robinson, C. W. and Zajicek, J. M. [12] analyzed the effects of the one-year school

${ }^{1}$ On this paper the term students refer also to pupils. 
garden program. They conclude that the youth that participated in the yearlong garden program enhanced teamwork skills and self-understanding also overall life skills. A school garden is considered as an 'innovative teaching tool and strategy that lets educators incorporate hands-on activities in a diversity of interdisciplinary, standards-based lessons' [10].

School gardens are also promoted by cities food strategies, the Mayor's Food Strategy proposes to 'promote existing opportunities for individuals and communities to grow food, through gardens, orchards, schools, allotments and parks and open spaces' also consider developing and expanding these in response to demand [13].

Those new approaches are essential to encourage social responsibility and educate future productive citizens. Local authorities have a crucial role in fostering these new approaches and reconsider the patterns of green school grounds toward productive and multifunctional approaches.

\section{Methods}

With a view to having a greater understanding of use and value of green school grounds in developing countries, case studies were done at five schools in Podujevo, Kosovo. Three primary ${ }^{2}$ schools; Naim Frashëri, Shaban Shala, and Enver Maloku and two secondary schools; Aleksandër Xhuvani and Fan S. Noli. Data collection include five interviews face-to-face with schools' directors and three interviews with municipal staffs including the representatives of the department for education in Podujevo. The interviews were realized from February to May 2018. The time spent per interview lasted between 30 and 60 minutes depending on how much information the school had to offer. The semistructured interviews consisted of a series of open and closed questions that explored the use, value,

\footnotetext{
${ }^{2}$ A primary school in Kosovo is a school in which children receive elementary and primary education, comes after preschool and before secondary school.
}

design, future plans, maintenance, children and staff engagement, teaching and outdoor learning on the green school ground. Also, the assessment through observation of green school grounds has been done by the author. Moreover, local documents have been analyzed including the urban development plan (2012-2022) and the Local Action Plan on Environment (2012/2017). Most of the documents belong to strategic planning as they provided long-term visions, objectives, and measures for further development of the planning area.

\section{Findings and Discussion}

This study found that majority of schools in Podujeve have vaster outdoor school grounds. However, the investments seem insufficient as several schools have very few trees or proper green school grounds. At this condition, most of the school grounds does not offer much to be utilized for environmental/experimental learning. All the schools analyzed have taught courses related to the environment, for instance 'the spatial environment' yet those courses remain at a theoretical level.

The front school ground of Fan S. Noli (Table 1) can be considered relatively maintained compare to other schools, there are some trees, pines and shrub pines planted but the variety is very limited. Planning and design of the site have been done by the school students of architecture department. Also, the planting has been done in collaboration with the students, municipality, teachers and donators. The director of the school Ms. Hajdini, V. [14] stated that they had required 100 more ornamental trees to be granted by DKA (Municipal Directorate for Education) and the request is still under review by DKA.

Also, Shaban Shala school (Table 2) have several green sites, but the type of trees is also limited (ornamental trees, pine and shrub pine). The municipality donated some of the trees and pines planted, and some are donated by students' parents.

In the process of planting and stewardship of green school grounds students are not much engaged only 
Table 1 Data of secondary school Fan S. Noli and green school ground views.

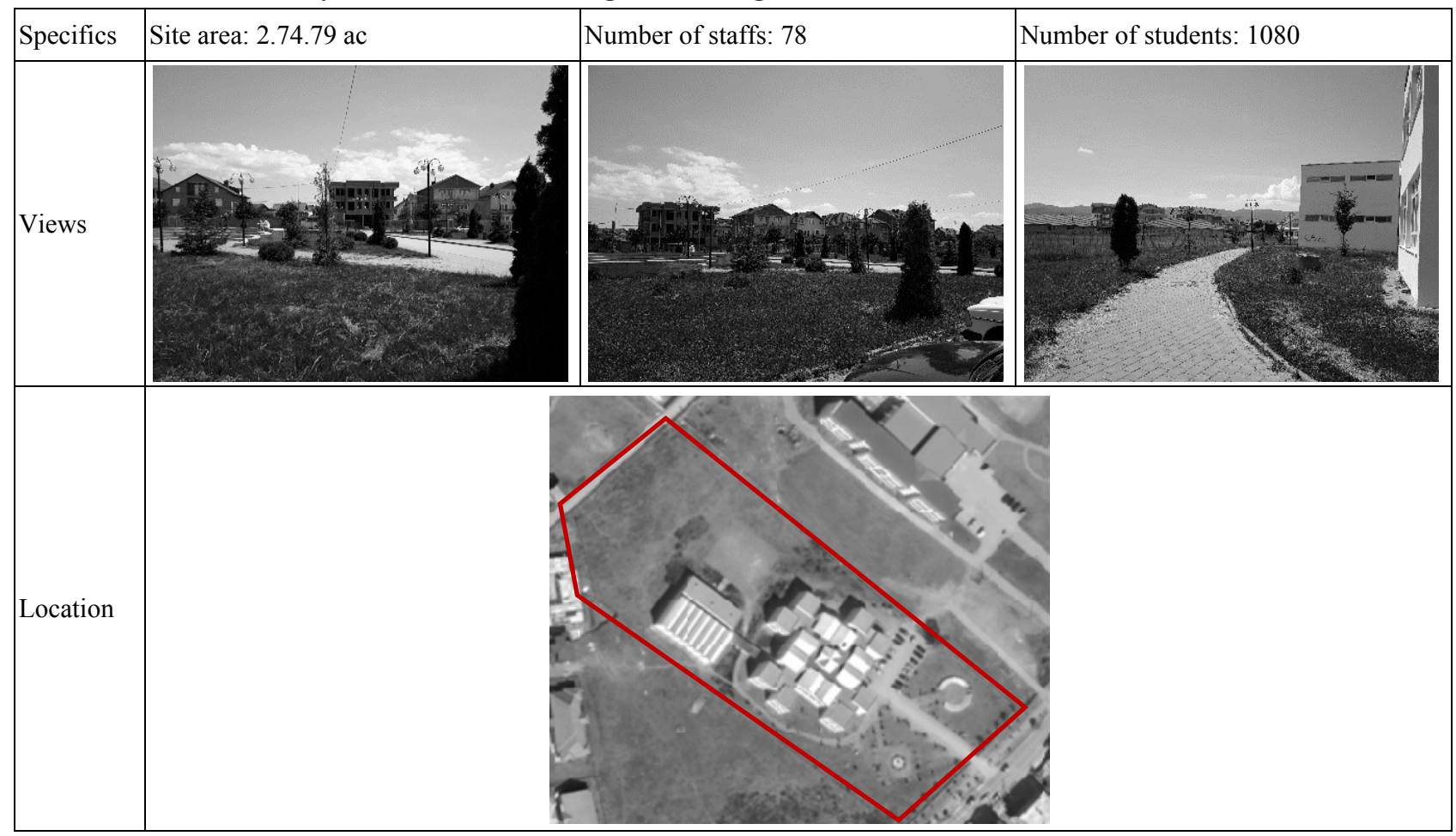

Source: author.

Table 2 Data of primary school Shaban Shala and green school ground views.

\begin{tabular}{|l|l|l|l|l|l|}
\hline Specifics & Site area: 87 acres & Number of staffs: 79 & Number of students: 1304 \\
\hline Views & & & &
\end{tabular}

Source: author. 
on special occasions or annual event celebration like 'Earth day'. It can be concluded that environmental stewardship is still a new concept and inapplicable, the maintenance of green areas is done mainly by technical workers of the school.

Another phenomenon found in this school is that around green areas there were fences (to protect from potential vandalism) that can increase the level of disengagement. Gardening and tree planting programs for children in surrounding environment has been proven to foster environmental stewardship and the positive values that comes from living with plants [15]. The limited interaction with nature in childhood experiences may lead to passive adults $[4,16]$.

The exchanged location of Aleksandër Xhuvani and Enver Maloku has prolonged the development of one site. The school's relocation was done in 2016, on the previous location of Enver Maloku, now is a new building of Aleksandër Xhuvani. Aleksandër Xhuvani school ground is not developed (Table 3) as the construction from 2009 have not been finished yet, said the director of the school Mr. Salihu, N. [17] During this year, they are expecting everything to be finished including the outdoor environment, having said that at the entrance of the school can be seen some shrub pines planted already. Neither this leaves much to be anticipated as the design does not include anything besides ornamental trees and pines. It can be highlighted that facilities offered on school grounds do not provide many possibilities for students' engagement. Moreover, it can be highlighted that those places are not much-valued from all instances, starting from the municipality, NGOs and at the school level. Both schools have spaciously but undeveloped school grounds. Based on the Local Environment Action Plans 2012/2017, Aleksandër Xhuvani (the current location of Enver Maloku's school) has been on the action plan-priority projects list. For a shared donation of 60,000 euro to improve school ground, allocated for implementation period in 2012. The project holders were municipality and donors (not specified) however, no investments were seen on the school ground based on current school ground conditions [18].

Based on empirical assessment, on the current school ground of Enver Malokuhas, very few trees planted as result of the initiative of the school director Mr. Hamza, A. [19], this initiative has been supported also by students and their parents. They have planted around 25 trees in 2017 as can be seen from the photos on Table 4.

The director of the school has required 500 ornamental trees at DKA and the ministry of agriculture, forestry and rural development but no donation were provided. The reason that municipality has rejected was the lack of budget while the ministry of agriculture, forestry and rural development did not classify green school grounds as a potential place for donation.

Dudek, M. [20] states that green school grounds should be merged to educational experiences because they can play a significant role in the process of developing knowledge. As many of the cases studied neither school ground of Naim, Frashëri can be utilized as a platform for the environmental educational experience. Despite that the school was built in 2016, the school ground is not in good condition. According to the deputy director $\mathrm{Mr}$. Hasani, B. [21] of the school, there was an investment on the school ground, where they planted grass and around 200 shrub pines, however, for unknown reasons, only few shrub pines survived.

School's technical workers have done planting of shrub pines, students were not engaged in the process. This year the school has planted few ornamental plants (flowers) with a small investment of parents and have engaged students on their activities (Table 5). The deputy director stated that they had required 200 ornamental trees but the DKA calmed that there is no sufficient budget [21]. 
Table 3 Data of secondary school Aleksandër Xhuvani and green school ground views.

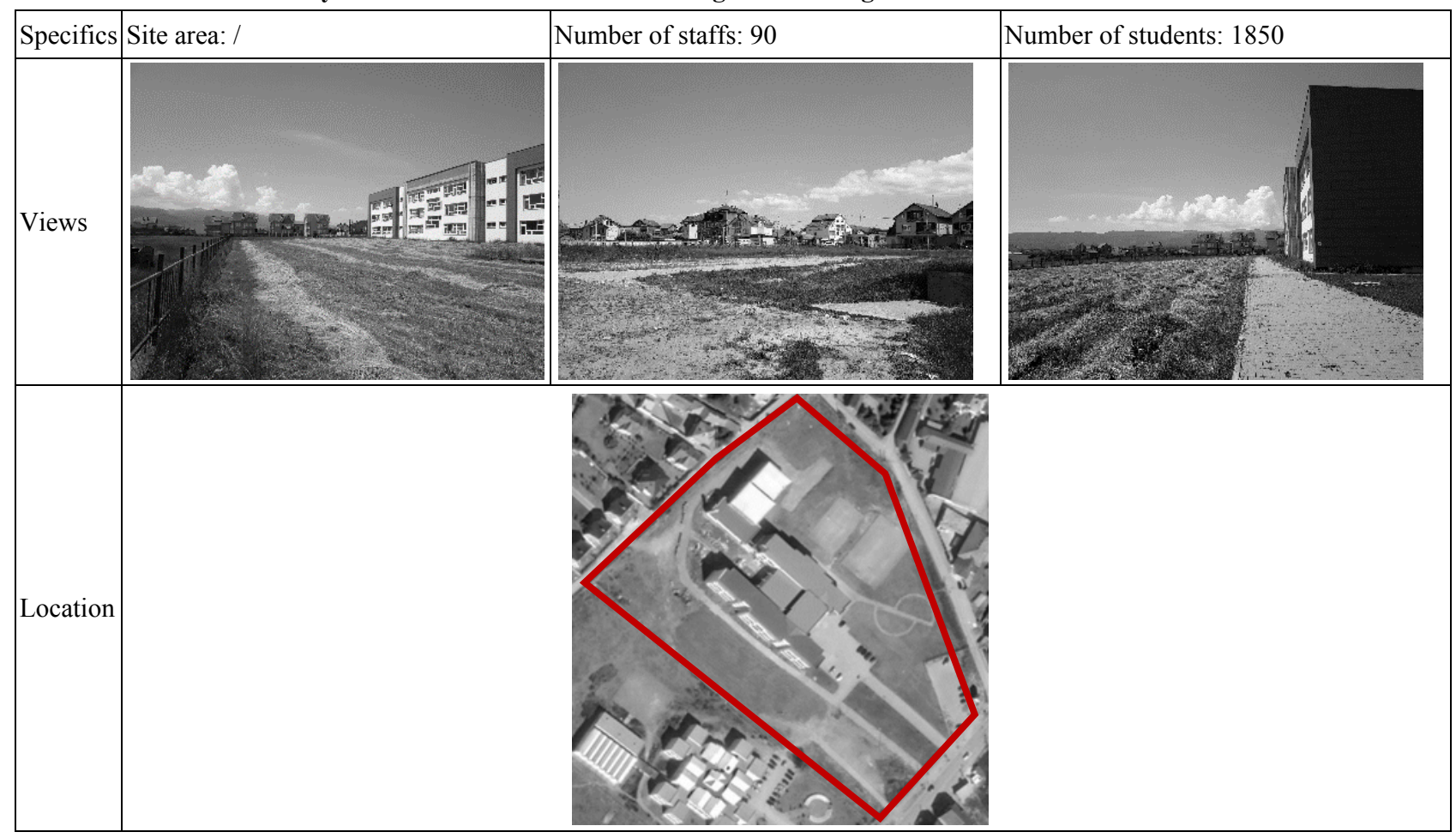

Source: author.

Table 4 Data of primary school Enver Maloku and green school ground views.

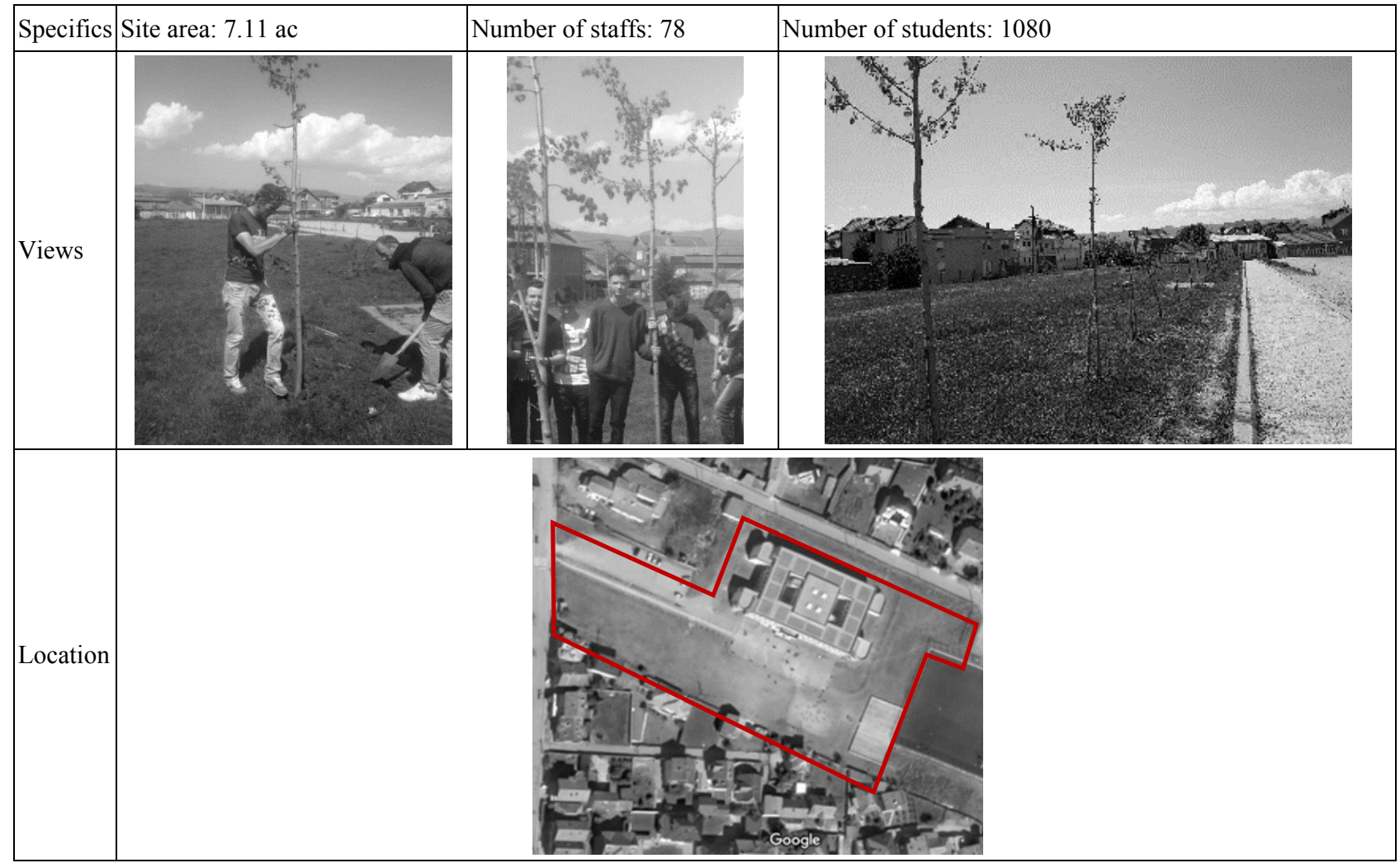

Source: author. Photos (C Hamza, 2018. 
Table 5 Data of primary school Naim Frashëri and green school ground views.

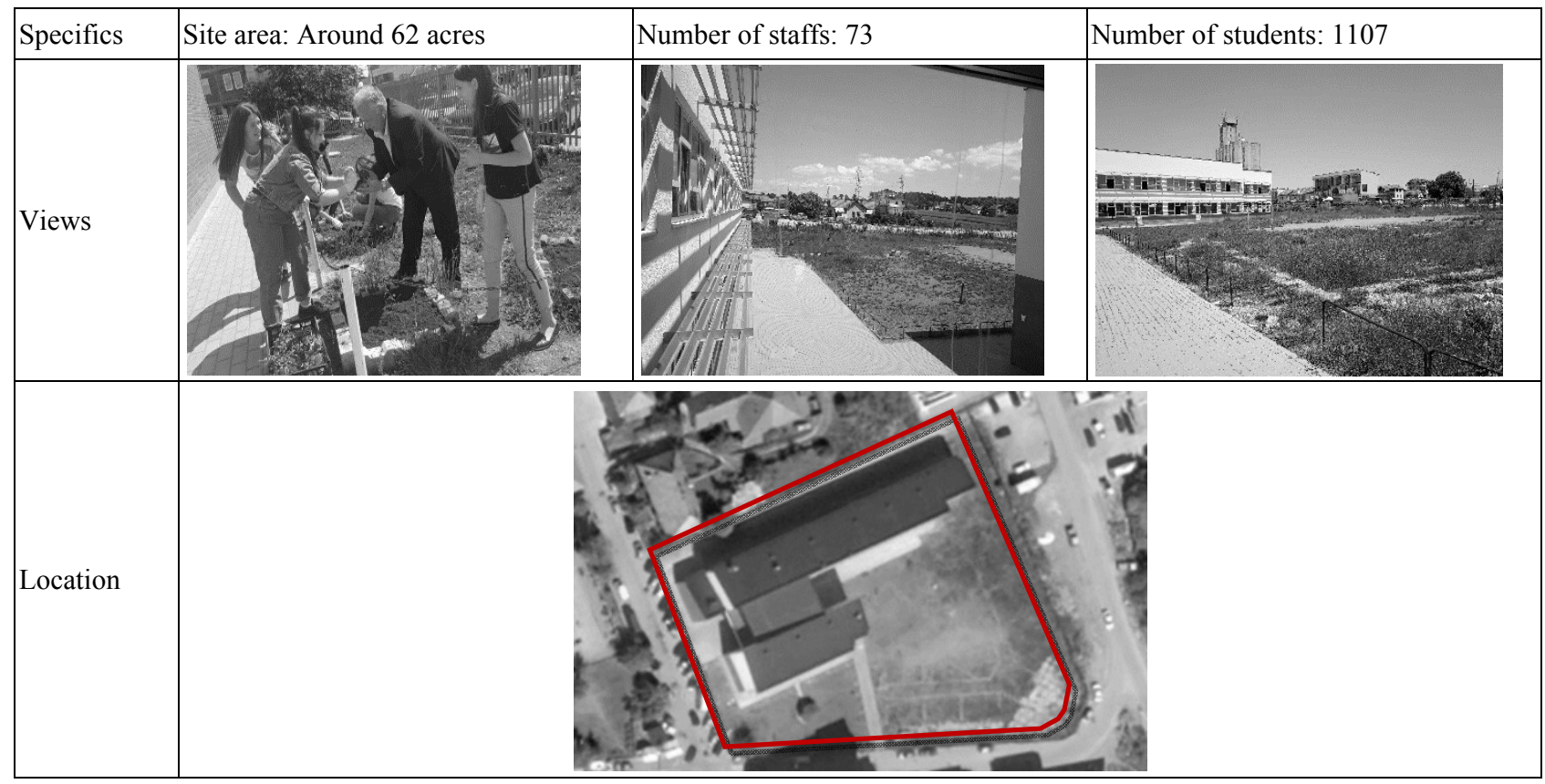

Source: author and photo with children (C) Hasani 2018.

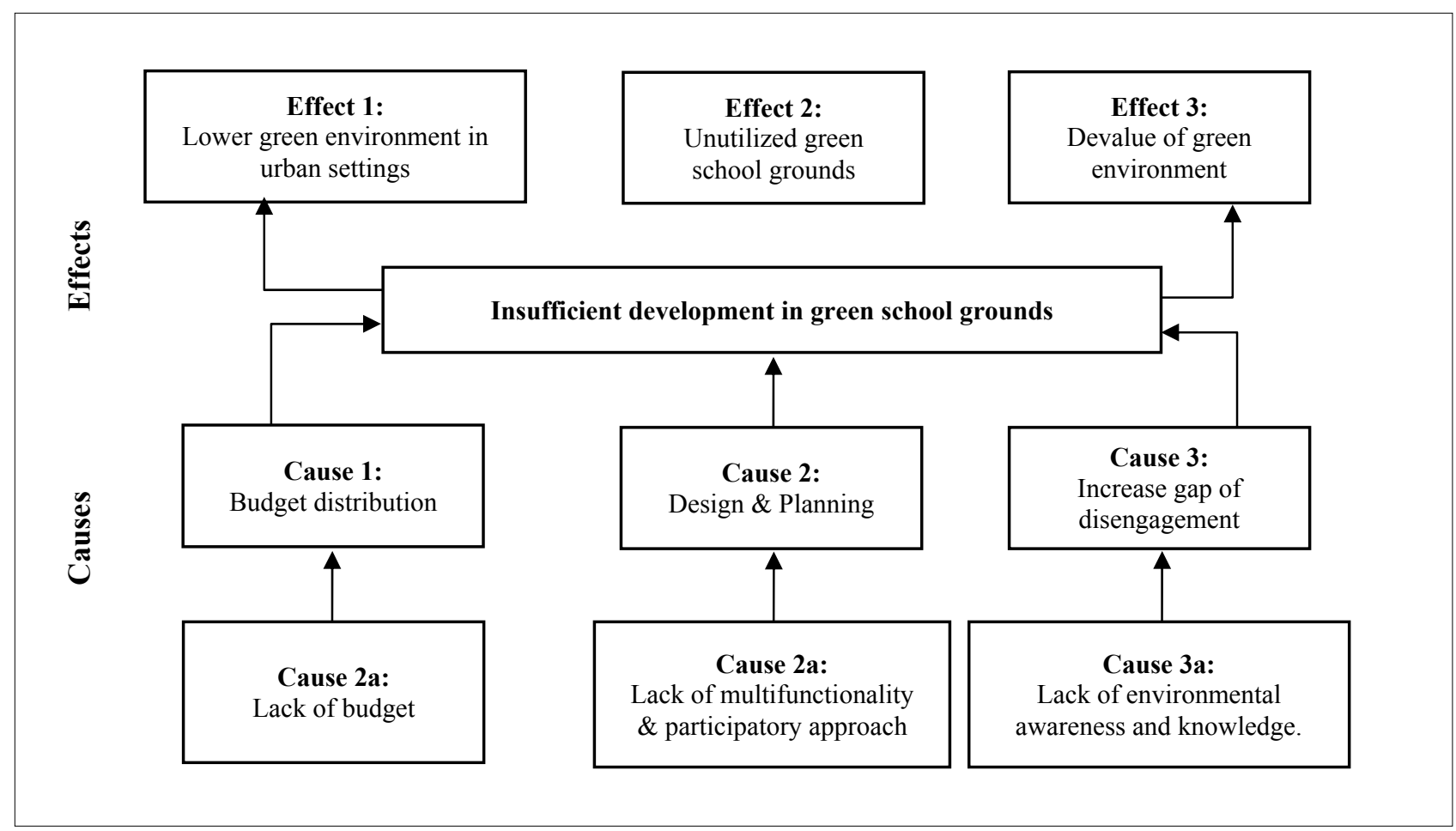

Fig. 1 Major challenges analysis: causes and effects of insufficient development in green school grounds. Source: author.

In the framework of the Local Action Plan on Environment, an allocation of 2000 euro in the so-called "Green Package of Education" for all schools [18]. However, this package (investment) is a bit unclear in its objectives and implementation. This package aimed to raise environmental awareness for students but with no practical possibilities that remain at a theoretical level. Moreover, on the project for 
enhancement of school grounds that were allocated 60,000 euro, there were no specification or linkage where emphasized the raising environmental awareness for students. The objectives of this project were to create "attractive place for students", and the expected results were to create "Beautiful view of schools and clean environment" [18]. Despite that, the lack of green spaces has been highlighted on Local Action Plan on Environment under the section of "Priority Issues List by Respondents". In the same time, the lack of environmental awareness is specified [18] but investments and planning do not show to create a mechanism to merge those issues. Green school grounds seem to be valued mainly for esthetical aspect. There was no proper consideration of values and use that school grounds can provide regarding social-cultural, ecological, functional and educational aspects. Fig. 1 presents intercorrelations of causes and effects of insufficient development in green school grounds. The lack of budget and proper management lead to insufficient and improper green school grounds. Planning and designing contributed to this uncertainty of enhancing green school grounds. Consequently, the disengagement is higher that can lead to devaluing of green environments.

\section{Conclusion}

In this paper, the value and use of green school grounds in Podujevo were analyzed. Major challenges in green school grounds were identified (Fig. 1). An analysis of planning documents revealed that the lack of green spaces and need for the rise of environmental awareness is targeted. However, the use of schools ground was not mentioned explicitly.

Green school grounds can provide opportunities for increasing urban green spaces and rising environmental awareness. Moore, R. C. [4] states that children gardening is the first steps towards a sustainable future. Green school grounds can be designed in more multifunctional approached and embraced environmental stewardship as a tool to connect children to nature. Thus, all actors involved should contribute to ensuring that green school grounds are designed and developed to provide excellent linkages for environmental, experimental learning. Moreover, school grounds could be considered as strategic places of increasing urban green spaces and as a platform for raising environmental awareness.

One option to adequately develop and maintain existing green school grounds might involve a focus on considering multifunctionality and offering opportunities for students to experience gardening in schools. This should be undertaken as part of a larger regenerative design process. In this context, the consideration of multifunctional approach helps to better communicate several benefits that student and citizens can gain from green school grounds. As Moore, R. C. [4, 22] highlighted, research and design programs should encourage the natural environment in the daily lives of children. In many societies, an increasing lack of emphasis on outdoor engagement is so prevalent today $[4,22,23]$. Finally, the case study of Podujevo may help to better understand the narrow and unproductive approaches for green school grounds design and development. Future research could include a comparative study which has some similar investment opportunities but fosters better and more sustainable solutions.

\section{References}

[1] Dyment, J. E. 2005. "Gaining-Ground: The Power and Potential of School Ground Greening in the Toronto District School Board.” Evergreen. Accessed February 9, 2018.

https://www.evergreen.ca/downloads/pdfs/Gaining-Grou nd.pdf.

[2] Titman, W. 1994. Special Places, Special People: The Hidden Curriculum of School Grounds. Godalming: WWF.

[3] Cutter-Mackenzie, A. 2009. "Multicultural School Gardens: Creating Engaging Garden Spaces in Learning about Language, Culture and Environment." Canadian Journal of Environmental Education 14 (1): 122-35.

[4] Moore, R. C. 1995. "Children Gardening: First Steps 
Towards a Sustainable Future." Children's Environments 12 (2): 222-32.

[5] UNESCO. 2009. "DESD Quarterly Highlights." UNESCO. Accessed April 30, 2018. http://www. unesco.org/education/DESDquarterlyAug09.pdf.

[6] UNESCO. 2016. Planet: Education for Environmental Sustainability and Green Growth. Global Education Monitoring report, Paris.

[7] Howard, E. 1899. "To-morrow: A Peaceful Path to Real Reform." The Economic Journal 9 (33): 71.

[8] Blair, D. 2009. "The Child in the Garden: An Evaluative Review of the Benefits of School Gardening." The Journal of Environmental Education 40 (2): 15-38.

[9] Bristol City Council. 2015. "One Tree Per Child." Bristol City Council. Accessed February 25, 2017. https://www.bristol.gov.uk/museums-parks-sports-culture /one-tree-per-child.

[10] California School Garden Network. 2006. Gardens for Learning: Creating and Sustaining Your School Garden. Irvine, CA: California School Garden Network.

[11] Colding, J., and Barthel, S. 2013. "The Potential of 'Urban Green Commons' in the Resilience Building of Cities." Ecological Economics 86: 156-66.

[12] Robinson, C. W., and Zajicek, J. M. 2005. "Growing Minds: The Effects of a One-year School Garden Program on Six Constructs of Life Skills of Elementary School Children." Hort Technology 15 (3): 453-7.

[13] London Developement Agency. 2006. "Healthy and Sustainable Food for London-The Mayor's Food Strategy." Accessed April 9, 2018. https://www.london.gov.uk/sites/default/files/the_mayors _food_strategy_2006.pdf.

[14] Hajdini, V. 2018, April 30. "Personal Communication (Interview), the Director of the School Fan S. Noli."

[15] Lohr, V. I., and Pearson-Mims, C. H. 2006. "Responses to Scenes with Spreading, Rounded, and Conical Tree Forms." Environment and Behavior 38 (5): 667-88.

[16] Louv, R. 2005. Last Child in the Woods: Saving Our Children from Nature-Deficit Disorder. Chapel Hill, N.C: Algonquin Books.

[17] Salihu, N. 2018, May 14. "Personal communication (Interview), the Director of the School Aleksandër Xhuvani."

[18] REC. 2012. "Local Action Plan on Environment 2012/2017.” REC. Accessed May 21, 2018. http://documents.rec.org/publications/LEAP_Podujeve_A L.pdf.

[19] Hamza, A. 2018, May 24. "Personal communication (Interview), the Director of the School Enver Maloku."

[20] Dudek, M. 2007. Schools and Kindergartens: A Design Manual. Walter de Gruyter.

[21] Hasani, B. 2018, May 29. "Personal communication (Interview), the Deputy Director of the School Naim Frashëri.”

[22] Moore, R. C. 1993. Plants for Play: A Plant Selection Guide for Children's Outdoor Environments. Berkeley: Mig Communications.

[23] Moore, R. C., and Wong, H. H. 1997. Natural Learning: The Life History of an Environmental Schoolyard. Berkeley, Calif.: Mig Communications. 